\title{
A GOOD FRIEND WILL HELP YOU MOVE A BODY: FRIENDSHIP AND THE PROBLEM OF MORAL DISAGREEMENT
}

\author{
The Philosophical Review 125.4 (October 2016) \\ Daniel Koltonski \\ University of Delaware
}

On the shared-ends account of close friendship, proper care for a friend as an agent requires seeing yourself as having important reasons to accommodate and promote the friend's valuable ends for the friend's own sake. However, that friends share ends doesn't inoculate them against disagreements about how to pursue those ends. This paper defends the claim that, in certain circumstances of reasonable disagreement, proper care for a friend as a practical and moral agent sometimes requires allowing your friend's judgment to decide what you are to do, even when you disagree with that judgment (and even when the judgment is in fact mistaken). In these instances, your friendship can make it the case that you may not act on your own practical and even moral judgments because, at those times, you have a duty as their close friend to defer to their judgments. As a result, treating your friend properly as a responsible agent can require that you assist them in committing what may in fact be serious moral wrongs.

\section{INTRODUCTION}

Friends do things for one another, and the closer the friendship, the more each is willing to do for the other. But how far might this willingness go? Are there limits to what close friends, as friends, should be willing to do for one another? ${ }^{1}$

For comments, objections, and discussion, I am grateful to Richard W. Miller, Nicholas Sturgeon, Michelle Kosch, Rochelle Duford, Bennett Helm, Lee Franklin, Karen Bennett, Kathleen Wright, Melissa Zinkin, Nishi Shah, Robert Dostal, Joel Yurdin, Matthew Schuler, Javier Hildago, Samantha Philbrook, Meena Krishnamurthy, and audiences at Cornell University, University of Houston, Florida State University, Dartmouth College, Purdue University, Columbia University, Princeton University, Virginia Tech, and the Creighton Club, to whom I presented earlier versions of the argument contained in this essay. I am especially grateful to Vincent Baltazar, Emily Muller, and Sara Streett for our many conversations and arguments about friendship, to Jyl Gentzler and three anonymous referees at this journal for the many suggestions that greatly improved the essay, and to Nathaniel Jezzi for always thinking that there was something right about the argument even when there were many things wrong with it.

${ }^{1}$ By 'close friendship' I mean that kind of close voluntary personal relationship between unrelated persons that is normally neither sexual nor romantic but is more intimate than, say, "work" or "school" friends or any other friendship that depends in large part on proximity for its survival. (This is not to deny that genuinely close friendships can have a sexual component. But such a sexual component is a complicating factor that does not bear on my discussion here.) Though hard to specify with precision, this kind of friendship is what Aristotle takes to be the core kind of friendship in the Nicomachean Ethics and what concerns most philosophical treatments of friendship, from Montaigne and Kant to, more recently, Laurence Thomas, Marilyn Friedman, Dean Cocking, and Jeanette Kennett. 
Consider the joke: "A friend will help you move house, but a good friend will help you move a body." The view of close friendship implicit here would seem to hold that there are very few limits to what friends are willing to do for one another, other than those limits that might be generated by the care for the other that's responsible for the willingness in the first place. In particular, this view would seem to hold that there are no moral limits to what friends are willing to do for one another. Friendship, on this view, has an inherent tendency to lead one into "moral danger": acting properly as a friend, doing for another what your friendship calls for, can require that you not act as morality demands. ${ }^{2}$ Thus, it would seem that a good friend is one who helps you move a body, even when morality forbids it.

But that cannot be correct. Suppose that you've committed premeditated murder and you must hide the victim's body to avoid discovery and arrest. One need not have an overly moralized conception of friendship to think that, in this sort of case, your good friend may refuse to help you move the body without thereby betraying the friendship. Friendship is a relationship of reciprocal care and concern - he cares for you, as his friend, as someone who cares about himand so if what you've asked of your friend is incompatible with proper care for him, you two are already outside of the bounds of friendship. Since enlisting him as an accomplice to clear and grave wrongdoing - here, covering up a murderis incompatible with proper care for him, his friendship with you doesn't require that he allow himself to be thus enlisted. Thus, it would seem instead that a good friend is one who helps you move a body, but only when morality allows it.

But this cannot be correct either. Consider that, on this second view, the joke no longer points to what seems a distinctive tension between friendship and morality, one that complicates the practice of friendship; instead, it merely observes that a good friend, unlike others, is willing for your sake to overcome their squeamishness at handling dead bodies. ${ }^{3}$ As a result, the joke loses much of its intuitive force, as it no longer reveals a surprising and uncomfortable truth about friendship. But, if neither view is correct, we're left with the question: What exactly is the uncomfortable truth about friendship that the joke reveals? In what sense is it true-and interestingly true - that a good friend is one who helps you move a body?

The first thing to observe here is that your friend's care for you is largely care for you as an agent, as someone with her own valuable ends (or projects or aims) that he, as your friend, shares. ${ }^{4}$ To care for a friend as an agent-to share the

2 This is the view defended by Dean Cocking and Jeanette Kennett (2000). See Cocking and Kennett $2000,279,292,296$. Their argument about friendship and moral danger is a narrower version of Susan Wolf's (1982) classic argument about the unsuitability of the 'moral saint' as a human ideal. ${ }^{3}$ A note on pronoun usage: I have opted at times for the singular "they" when referring to a generic person, both because doing so avoids the awkwardness of "he or she" and because it is maximally inclusive (since not every person is either a "he" or a "she"). However, when assigning genders makes things clearer (for instance, when talking about a situation involving two friends), I have done that instead.

${ }^{4}$ This claim concerns what Kyla Ebels-Duggan $(2008,143)$ calls "the practical element" of lovethat is, those practical reasons that, in virtue of loving a person, you must regard that person as giving you. For various accounts of the practical aspect of love (or care), see Ebels-Duggan 2008, 
friend's ends - is, in part, to see oneself as having important reasons to accommodate and promote the friend's pursuit of the valuable ends they have adopted and to do so for their own sake, for it is then that one cares for the friend as someone with an important interest in responsibly exercising their agency in their own life. ${ }^{5}$ Why does your friend's care for you take this form? It does so because it is only then that his care for you is compatible with the general moral demand of respect: since he must interact with you, as with anyone, in ways that show proper respect for you as an agent, his care for you as his friend must be care for you as an agent. Friendship is, in this way, internally structured by morality, and so the reasons generated by the fact that his care must be of this character-care for you as an agent-are not only reasons of friendship but also moral reasons. ${ }^{6}$

Putting this sort of care into practice, however, is a complicated endeavor. For instance, that a friend shares the other's end, and so is moved to accommodate and promote the other's pursuit of it, does not inoculate those friends against disagreements about how to jointly pursue that end. The possibility of such disagreement is inherent in the relationship. And we cannot simply say that, when friends confront such disagreements, each should just go their own way, doing whatever they each judge right or appropriate, at the cost of making joint action in pursuit of the end impossible. Why not? We cannot because many such disagreements often do not simply concern what means they together should adopt. In the usual cases, the decisions at issue are not merely technical ones about how to pursue some already defined end but rather decisions that, in being made, both define the end further and help locate it in a system of priority with the person's other ends. ${ }^{7}$ Thus, decisions about how to pursue a friend's end will often also amount to decisions about the nature and relative importance of that end, decisions one might think are appropriately left up to the friend, the agent whose end it is.

My aim in this essay is to refine and defend this thought that the decision ought to be left to the friend whose end it is. In certain circumstances of disagreement between friends, doing what one judges right or best will count as

Cocking and Kennett 1998, Frankfurt 1999, Kolodny 2003, Raz 1989, Scheffler 2001, and Westlund 2009.

${ }^{5}$ There is a dispute in the literature about the practical reasons close friendship gives rise to: Frankfurt (1999) argues that they are reasons to promote the friend's well-being, while EbelsDuggan (2008) argues that they arise out of sharing in your friend's ends. Though I side with EbelsDuggan, I expect that these views are not very far apart, once we understand a person's well-being as including, in large part, the realization of their ends. For discussion, see Ebels-Duggan 2008, 14855, 168-70, as well as Raz 1986, 305-13.

${ }^{6}$ This claim that friendship is in this way internally structured by morality is a relatively narrow one: affirming it doesn't require claiming that the partiality that friendship requires can be fully reconciled with what morality demands, as that question is largely about reconciling this partiality with morality's demands on you concerning people other than your friend. For two views to the contrary, see Scanlon 1998, 164-66, and Herman 2008, 335-36. I thank Nathaniel Jezzi for discussion on this point. For related claims about the norms of friendship and morality, see Korsgaard 1992, 306-7.

${ }^{7}$ As Joseph Raz $(1986,292)$ notes, “many of any person's goals [or ends] are nested in his own complex goal structures." 
failing to share the friend's end in the right way-as an end that, though shared, is still the friend's - and this failure, as a failure to care for the friend properly as an agent, is not just a failure of friendship but also a moral failure. When their disagreement satisfies two conditions to be described, the two friends no longer confront the question, "What are we (together) to do?" - as this is what they disagree about-but rather the different question, "Which of us is to decide what we (together) are to do?" And, that they are friends will be relevant to answering this latter question: for one of the friends, proper care for the other as an agent will require that he defer to her judgment or, in other words, it will require that he allow her judgment, rather than his own, to decide what he is to do, even when he disagrees with her judgment and even when her judgment is, in fact, mistaken. In this kind of disagreement, deferring to her judgment-letting it determine how they will pursue her end -is what it takes to care for her as a responsible agent. ${ }^{8}$ And, importantly, this will be true even when the practical judgments in question are (or imply) moral judgments, judgments about what morality permits or requires. Or so I will argue. ${ }^{9}$

In what sense, then, is it interestingly true that a good friend is one who will help you move a body? Suppose you want your friend's help moving a body, but he thinks that moving the body is impermissible. Of course, he cares for you and wants to help you - friendship pulls him in one direction - but what you want help doing is, by his lights, impermissible - and so, morality seems to pull him in another. As he sees the situation, there is a tension between the demands of friendship and those of morality. But, if his disagreement with you meets the two conditions to be described, the appearance that morality pulls in another direction will be illusory: his care for you, if it is to be care for you as a responsible moral agent, requires that he defer to your judgment that moving the body is permissible. And so, a good friend is one who, when facing this sort of

8 The argument makes use of a justificatory strategy sketched by Samuel Scheffler (2001). He argues that we can justify a person's special responsibilities by showing that the relationship in question is noninstrumentally valuable and that they cannot value this relationship in the right way without seeing themselves as having these special responsibilities. My argument here is that a certain kind of close friend cannot value their friendship in the right way-as a relationship of mutual care with another agent-without seeing themselves as having a duty sometimes to defer to their friend. 9 That one's friendship with another can give one a duty to defer to that other is not much discussed in the literature on friendship. One notable exception is Philip Soper (2002). Soper's argument, however, casts the situation as one of "competing moral goods": "We weigh the prima facie value of maintaining the relationship against the prima facie dis-value of acting incorrectly and discover that sometimes the correct action (in the ultimate sense) requires a compromise of our own (correct) views about what to do" (Soper 2002, 19). My claim that the friends' duty to defer is a constitutive duty of friendship is different, for, as a constitutive duty, I can have it even though fulfilling it may end the friendship rather than help preserve it. It is a familiar phenomenon that sometimes being a good friend requires acting in ways that risk the demise of the friendship. For more on constitutive duties and friendship, see Raz 1989, 19 and $\operatorname{Raz} 1986,212$. Another exception may be Marilyn Friedman (1993). In her observation that a friend's judgments, because they are your friend's, "may provoke [y] our reflection or, even, deference" (Friedman 1993, 191), she does not specify whether she means epistemic or what I will call "practical" deference, and I am concerned only with the latter sort. Michel de Montaigne (2005 [1580], 10-13) also seems to include something like a duty to defer in his discussion of perfect friendship, though whether he does is complicated by his insistence that perfect friends do not disagree with each other about what to do. (It is a duty, then, that is never activated, at least in perfect friendships.) 
disagreement with you about moving a body, will defer to your judgment that moving the body is permissible, rather than act on their own (conflicting) judgment, and so will help you move the body. Their willingness to defer to you here does not lead them into moral danger, for they will be morally justified in helping you, even if you're mistaken that moving the body is permissible.

In the end, the account developed here makes plain one important and underappreciated way in which valuable personal relationships make the task of abiding by the demands of morality a more complicated endeavor than one might have thought. In certain circumstances, the appropriate question confronting a person, from the perspective of morality, is not the standard "What am I to do here?" but rather "Who is to decide what I am to do here?" And sometimes the right answer, from the perspective of morality, is that some other person is to decide. The responsible exercise of one's moral agency sometimes requires allowing another to exercise their moral agency in its stead. This claim, applied to close friendship, is arguably the surprising and uncomfortable truth the joke reveals.

\section{FRIENDSHIP AND DEFERENCE}

The claim I advance here is that friendship, paradigmatically a relationship between equals, can give one friend a fairly demanding duty to defer to the other. What exactly is this "duty to defer"? Roughly put, to abide by a duty to defer to another is to do something not because you judge it to be the appropriate, right, or good thing to do in the circumstances, but because the other judges it to be so. More precisely, it is to treat that person's judgment that you should do $x$ in some situation as by itself a presumptively conclusive reason for you to do $x$, or, in other words, as a powerful reason to do $x$ that also disallows acting on your own judgment of what to do in that situation. By deferring to another, you replace in your deliberations your judgment of some situation with that other person's, and you do so not because you think that other person's judgment is correct but rather because it is hers. In this way, the sort of deference at issue here is not epistemic deference: this other is not necessarily more expert, and you need not think you have reason to believe that her judgment is correct or more likely to be so than your own. ${ }^{10}$ The deference at issue is better described as practical deference: though you may still disagree with her, that she makes the sort of practical judgment she does gives you presumptively conclusive reason to let her decide what you are to do. ${ }^{11}$

\footnotetext{
${ }^{10}$ There is an extensive literature in epistemology on the significance of disagreement between persons. See, for instance, Christensen 2007, Elga 2007, and Kelly 2005. For my purposes, I assume that, in the instances of reasonable disagreement at issue, it is rational for each person to make the judgment they make, even after recognizing that the other-an epistemic peer-disagrees. I use 'epistemic peer' here somewhat loosely, however, for, in the cases at issue here, neither knows whether the other is an epistemic equal.

11 Those familiar with Joseph Raz's account of practical authority will notice that, when you have a duty to defer to a person's judgment in the sense at issue here, that person's judgment will be, on Raz's account, practically authoritative for you. It might be objected that, since authority relations
} 
Why think that friendship is partly constituted by a duty sometimes to defer to the other's judgments? Kyla Ebels-Duggan (2008) has recently defended "the shared ends view" of the practical aspect of love. On her account, loving another "as a full-fledged agent... well-functioning enough to have sovereignty over [her] own life" directs you to share in her ends, to do things with her in pursuit of those ends (Ebels-Duggan 2008, 147, 156). Sharing another's ends, she claims, requires that you regard this other as having a distinctive kind of practical authority over you, what she calls "selection authority": "by choosing from among the set of permissible projects, [the other] gives you reason to pursue those chosen ends with her rather than concentrate your efforts on some other worthwhile pursuits" (ibid., 156). ${ }^{12}$ It is the reciprocal recognition of this selection authority that partly enables friends to pursue shared ends in a way that preserves each friend's status as an agent with ends that, though shared by the other, are still their own.

Treating a friend as an agent with ends that, though shared, are still her own doesn't only require that you regard her selection of those ends as authoritative, however. It also matters how you pursue those ends with her. As Ebels-Duggan notes, for many of a person's ends, what matters is not simply that something be done but also that she herself is the one who does it. These ends are what Joseph Raz calls "agency goals," that is, ends "that others can help [the person] reach, by providing the right environment, the right conditions. But they cannot reach [these ends] for him" (Raz 1986, 306). Consider Ebels-Duggan's example:

Suppose that your brother aims to write a novel. ... His choice to pursue the end... gives you very different reasons than it gives him. It gives him reason to form a plot, develop characters, and set aside time for concentrated writing. You should regard yourself as having reasons to accommodate and promote his doing these things. For instance, you should respect his aim to spend afternoons writing by not dropping by for unannounced visits. If you share his end fully, you also take it to give you reason to take positive measures. You might, for example, read and

are incompatible with friendship as a relationship of equals, a friend cannot have a duty of friendship to defer to the other. However, to say that one friend's judgment can be authoritative for the other is not yet to say that this other is subject to their authority in any troubling sense. It's not the claim, for instance, that this other stands in a nonreciprocal relationship of regular deference to the friend's directives, deference that the friend is entitled to demand. Rather, the claim here is that each friend sometimes must defer to the other; thus, they don't stand in the sort of authority relations toward one another that would be incompatible with friendship as a relationship of equals. For Raz's account, see Raz 1986, chaps. 2-4. For a related account, see Shapiro 2002. And, in fact, Abraham Sesshu Roth $(2004,2013)$ has recently proposed that the best way to understand the origins of the "distinctive interlocking structure of intentions" (Roth 2013, 1) involved in shared activity as such is that one participant exercises a kind of authority over the matter at hand, and so over the other participant(s), by issuing an intention that the other participants act on directly. Roth also thinks that this kind of authority is compatible with the equality characteristic of friendship in that, while one friend may have it in some situations, the other will have it in some other situations. I thank an anonymous reviewer for bringing Roth's work to my attention.

${ }^{12}$ Christine Korsgaard $(1992,307)$ makes a similar point in her discussion of Kant: "While love moves you to pursue the end of another, respect reminds you that she must determine what those ends are." 
comment on his drafts. The point... is that sharing in this end doesn't require you to adopt the same project that he does: you don't aim to write the novel. Rather, it requires you to accommodate and promote his end, that is, his writing of the novel. (Ebels-Duggan 2008, 156-57)

When it comes to a friend's agency goal, then, you cannot properly share it by appropriating it as something you may do for her because such appropriation misunderstands her end. Your sharing of it must be done in a way that acknowledges it as hers in a more robust sense - she has an interest in exercising her agency in direct pursuit of the end that you do not-and you share it in that way by taking yourself to have reason to assist her in her pursuit of it.

Treating these shared ends as hers in this more robust sense, however, requires that you recognize your friend as having another kind of authority, one that Ebels-Duggan's account overlooks. To see this, consider first her remarks about the limits of a friend's selection authority:

Now imagine that your partner proposes to undertake an end that you regard as flatly impermissible... Here we run up against a limit on the beloved's authority: the provisional adoption of an impermissible end simply can't generate reasons for you. You may still owe it to your beloved to consider her view that it would not be impermissible to undertake the project in question, if indeed this is her view. But, in the end, you will have to rely on your own considered judgment about this. (Ebels-Duggan 2008, 162)

On Ebels-Duggan's view, your friend's selection authority runs out when she selects an end that you find morally impermissible; that she judges it permissible doesn't itself give you reason to share that end with her. ${ }^{13}$

Now, suppose instead that while you agree that the end itself is permissible, you think that, under the circumstances, it is impermissible to pursue that end altogether or at least in the way your friend proposes. A natural extension of Ebels-Duggan's claim above would be to say, about these cases, that your friend has no authority over the manner of your joint pursuit of her ends that overrides your moral judgments about the manner of their pursuit. On this view, you may, consistent with the demands of friendship, act on your own moral judgments and so refuse to do what you judge impermissible-even when doing so means declining to help your friend pursue some end, one that you otherwise share, in the way that she judges appropriate.

However, as I will argue in the following sections, there is one important class of disagreements over how to pursue a shared end about which this view is mistaken: when it comes to these disagreements, you may not, consistent with treating your friend as a full-fledged agent with sovereignty over her own life, act on your own considered judgment about how to pursue the end. For these, then, the question of authority (and so deference) does arise. These are disagreements, including moral ones, that meet two important conditions:

${ }^{13}$ For a similar claim about such cases, see Westlund 2009, 3. 
1. Particular agency interest (PAI): The two friends disagree about what they together are to do, but one friend has a particular interest in exercising their agency with regard to this question - the end(s) at stake or implicated here is (are), in the first place, their end(s) - while the other friend does not.

2. Reasonable judgment (RJ): The friends' disagreement about what they together are to do in pursuit of the shared end cannot be explained, wholly or in part, by appeal to flaws in the deliberations of the friend who has the particular agency interest here.

When the friend has a particular agency interest in the matter at hand (and you do not) and her judgment of the matter is reasonable, sharing her end in the right way requires deferring to her judgment about how jointly to pursue that end. And this requirement for sharing her end holds even when the disagreement is a moral one: so long as her judgment that it is permissible to pursue the end the way she wants is a reasonable one, you must defer to it; otherwise, you fail to care for her as a full-fledged agent with sovereignty over her own life. Such a failure is not simply a failure of friendship but also a moral failure. ${ }^{14}$

\subsection{Deference as a Duty: A Case}

The main claim about the friend's duty to defer concerns the other's reasonable moral judgments. But, before defending that claim, we must first establish that close friendship gives rise to a duty to defer at all, since some might doubt that such a duty is ever a feature of everyday interpersonal interactions that are outside of institutionalized authority relationships. To address this initial doubt, consider the following case, one that doesn't involve close friends but only acquaintances:

Promised Help: One weekend, Subrena's acquaintance Neelam calls her. Neelam is auditioning that week for the role of Blanche DuBois in a production of $A$ Streetcar Named Desire, a role that could be her big break. Earlier that week, Subrena had run into Neelam. During their conversation then about Neelam's upcoming audition and her hopes for a career in the theater, Neelam had expressed her worry that, because most of her friends were also auditioning for parts, no one would be able to give her any last minute help preparing for the audition: "I hope I'll be ready by then because I don't think anyone will be around." Responding to Neelam's concern, Subrena had promised her that she would help her rehearse her lines this weekend if she needed it. Now it's the weekend. Neelam says, "I know you'd probably rather do something else with your weekend than help me rehearse, but my friends are all busy preparing for

\footnotetext{
${ }^{14}$ The deference at issue here is thus quite far from the sort of thoroughgoing deference that Thomas Hill (1991) made famous in his discussion of "the Deferential Wife." For an illuminating account of why this sort of thoroughgoing (or, "self-abnegating") deference is a pathology of agency, see Westlund 2003.
} 
their auditions. I really need your help." It seems to Subrena, however, from other things Neelam had said, that Neelam does not really need her help-she's been preparing for weeks and she has both the lines and the character down cold - and Subrena can imagine that, were she to help her, the extra practice would be counterproductive by making Neelam overprepared. Still, Neelam thinks that she needs Subrena and that Subrena, because of her promise, should help her.

In this case, it's clear that Subrena ought to help Neelam rehearse her lines, even though she thinks that Neelam doesn't need her help, because she promised that she would. Indeed, one might think, that's just what promises do: they commit the promisor to certain courses of action. But that's not quite what Subrena's promise has done. Strictly speaking, it doesn't commit Subrena to helping Neelam; rather, it commits Subrena to acting on Neelam's judgment of whether she needs her help. If Neelam decides that she needs Subrena's help, Subrena must help her whether or not she agrees with that judgment; and, if Neelam decides that she doesn't need it, and so Subrena doesn't help her, Subrena can still count as having kept her promise so long as she stood ready to help. Thus, the duty Subrena has created is a duty to defer to Neelam's judgment about whether she is to help her.

Indeed, it is in virtue of creating this duty to defer that Subrena's promise is valuable for Neelam, for it gives her sufficient grounds to rely on Subrena's availability as an option when deciding how to prepare for her auditions. Because Subrena has done more than simply state an intention to help Neelam should she need it, or, more precisely, an intention to help her should Subrena judge that she needs it, Neelam can count on Subrena's availability to help her. In this way, this promise is valuable even if Neelam decides that she does not need help after all, since what matters is that, by ensuring that Neelam has this option, Subrena takes steps to ensure that it is up to Neelam whether someone helps her rehearse. ${ }^{15}$ Subrena makes it the case that, in this small way, how Neelam prepares for her audition is determined by her own judgments rather than determined for her by circumstances or by others (as it would have been had she judged that she needed help but could find no one to help her). By making such a promise and thus creating a duty to defer, Subrena shares Neelam's end-in a narrow, one-off way appropriate for acquaintances - and she does so in a way that recognizes Neelam's end as an agency goal. ${ }^{16}$

${ }^{15}$ And so, we see why Subrena's promise that she'll help Neelam if Neelam decides that she needs it is not just a long-winded way of promising Neelam that she'll help her. With the former promise, Subrena explicitly leaves it up to Neelam to decide whether she will help her. With the latter promise, Subrena would make helping Neelam the presumptive course of action; and, while Neelam can annul this presumption by releasing Subrena from the promise, it will in normal circumstances steer Neelam toward using Subrena's help, and this steering effect isn't fully compatible with leaving the decision up to her. I thank Jyl Gentzler for discussion on this point. ${ }^{16}$ This discussion of Subrena's promise, despite being a promise between acquaintances, is inspired by Seana Shiffrin's account of promises between intimates: "Promising to $\phi$ conveys [to A, the promisee] B's willingness to forswear the moral right to alter course. B's participation is no longer dependent on how $\mathrm{B}$ perceives the merits of the activity at the time of action. The promise acknowledges A's investment in the situation in a way that includes A rather than making $\mathrm{A}$ a 


\subsection{Deference as a Duty of Friendship: A Case}

We have seen that certain acts, such as making a promise, can commit a person to deferring to another's judgment. But it is also the case that friendship can give rise to a duty to defer. Consider the following case. Here, two friends face a disagreement about what they together will do, a disagreement that, because it concerns only the friends' interests, is confined to the friendship:

Friend's Audition: On the same weekend as Promised Help, Rosa's good friend Clara calls her. Clara, like Neelam, is auditioning that week for the role of Blanche DuBois, and this role may prove her big break. As her good friend, Rosa is well aware of Clara's ambitions in the theater, and she respects her talent and potential very much. Clara says, "I know you'd probably rather do something else with your weekend than help me rehearse, but my other friends are all busy preparing for their auditions. I really need your help." Rosa doesn't have any plans for the weekend (and Clara knows this); but she also finds helping others rehearse their lines somewhat tedious and dull. And it seems to Rosa from their previous conversations that Clara doesn't really need hershe's been preparing for weeks, and she has both the lines and the character down cold - and Rosa can imagine that, were she to help her, the extra practice would be counterproductive by making Clara overprepared. Still, Clara thinks that she needs Rosa and that Rosa, as her friend, should help her.

Clara and Rosa disagree about whether Clara needs Rosa's help. But Rosa, unlike Subrena in Promised Help, is not bound by any prior promise to help Clara should Clara decide that she needs it; she is bound, instead, by their friendship to share Clara's ends. And it is clear here that Rosa, as her friend, ought to help Clara rehearse her lines. But what explains this? It seems to me that Rosa has a duty here to defer to Clara's judgment about what the joint pursuit of her end requires here-it requires that Rosa help Clara rehearse - rather than act on her own judgment of what that pursuit requires - that she decline to help.

Clara's judgment that Rosa should help her is a reasonable one. And Clara has a particular interest in exercising her agency here-it is her success in the audition that's at stake - while Rosa does not. Rosa must take Clara's judgment seriously as a judgment about how to pursue her end, and taking it seriously as a judgment requires that, in Rosa's deliberations about whether to help Clara rehearse her lines, she replaces her judgment of whether Clara needs her help with Clara's judgment. It is by doing this that Rosa responds appropriately to Clara's interest in exercising her agency, for it is Clara's judgment that Rosa makes effective by helping her rehearse her lines. Rosa, of course, will still ultimately act on her own judgment: she judges that she ought to help Clara. But

bystander to what unfolds. ... The promise to A does not just increase the likelihood of B's performance... but actively affirms A's status as a free person, capable and worthy of exercising sound judgment about what is to be done" (Shiffrin 2008, 507-8). For related discussion, see Fried 1981, 13-14. 
this judgment, if it is to express proper respect for Clara as a responsible agent, is of a particular sort: "This is Clara's decision to make, and her judgment that she needs me is reasonable. As her friend, I ought to defer to her about this." Thus, Rosa shares Clara's end in the right way, as an end that is still, in the relevant ways, Clara's own.

Some might doubt that deference is needed to explain why Rosa ought to help Clara. After all, one might think, when helping is not burdensome, a friend simply has reason to go along with the other's wishes. In Friend's Audition, Clara is not asking much of Rosa and were Rosa to refuse her help, not only would Clara be disappointed - she would have no one to help her-but her disappointment, directed at Rosa, would likely damage their friendship. Rosa ought to help her, but not because Rosa ought to defer to Clara's judgment; rather, she should simply go along with it so as to please Clara. On this proposal, then, what friendship requires is merely that Rosa humor Clara. ${ }^{17}$

Admittedly, humoring a friend-going along with her judgment-is sometimes appropriate, but it is as a sort of triage, as a way of minimizing any damage the disagreement might cause. As triage, however, it seems appropriate only when the friend is being unreasonable-her reasoning is clearly mistaken but, for whatever reason, she cannot be made to see the mistake-for the aim of humoring her is simply to get through the situation and on to other things. But this is not the case in Friend's Audition: though Clara may be mistaken, her judgment is far from unreasonable. Humoring Clara, treating her judgment as unreasonable but not worth correcting, would thus betray an attitude of condescension incompatible with proper respect for Clara and her capacity for responsible agency. ${ }^{18}$ This proposal, then, fails to explain why Rosa ought to help Clara.

Another proposal would be to say that though Rosa is indeed right to help Clara, it is not because she must defer to Clara's judgment but rather because Clara's interest in exercising choice outweighs her other interests here and so allowing Clara's choice to be effective is how Rosa best promotes Clara's good. Clara, of course, wants to give the best audition she can, since this end is an important part of her more comprehensive end of a successful theater career. But, this proposal notes, this end of a successful audition is an agency goal: it is not only important that Clara's audition goes well but that she herself brings it about that it goes well; and, since one of the ways that she brings it about herself is by deciding how to prepare for it, she has important reasons to exercise choice in

${ }_{17}$ On Soper's account, this explanation is one way to justify deferring to another's judgment: when deciding whether to go along with a friend's judgment, "I must take into account not only my partner's disappointment if I do not [go along with her judgment], but also the potential impact on the relationship" (Soper 2002, 25). Though Soper calls this sort of "going along" deference, it does not count as deference on my use of the term; it can merely look like deference.

${ }^{18}$ Even in those cases when one friend is right to humor the other in this way, she normally shouldn't admit to the other that she is merely humoring him: because the other thinks (mistakenly) that his judgment is reasonable, such an admission would be seen by him (mistakenly) as expressing an attitude of condescension. It is really only later, once the other has realized that his judgment was unreasonable, that it will be appropriate for the friend to admit that she had merely humored him. 
Friend's Audition.

On this proposal, then, Rosa ought to help Clara rehearse because doing so is the way, in this situation, for Rosa to be appropriately responsive to Clara's interest in exercising choice: by helping her, she allows her choice of how to prepare for her audition to be effective. Admitting in this way that Clara has an interest in exercising choice separate from those interests promoted by choosing well-and that Rosa ought to promote this interest, possibly at the expense of the others-does not, however, get a duty to defer, since this interest, as one of several, simply gets included with the others in Rosa's deliberations about whether Clara needs her help. This proposal, then, is a particular challenge because, on its account, Rosa's decision to help Clara, though not a decision to defer to Clara's judgment, nevertheless seems to take Clara seriously as a fellow agent: Rosa's task, as Clara's friend concerned to promote her good, is to weigh Clara's conflicting interests correctly, and sometimes, as in Friend's Audition, her interest in exercising choice wins out over the others.

The problem with this proposal, however, is that, by treating Clara's interest in exercising choice as just another interest among several, Rosa's deliberations about whether to help Clara betray a (more subtle) attitude of condescension toward Clara and her capacity for responsible agency. Consider Clara's judgment that she needs Rosa's help. This is a judgment about what, in this situation, would best promote those various interests at stake in her pursuit of a successful audition. But now consider Rosa's deliberations according to this proposal. She must judge what, in this situation, would best promote those various interests that are at stake for Clara, but now Rosa must add Clara's interest in exercising choice into the mix, and this latter interest competes with these others. Which interests win out, however, depends on how Rosa's deliberations go, on the weights she assigns to these other interests in light of her understanding of the situation and of Clara, her ends, and so forth. On this proposal, then, whether or not Rosa allows Clara's judgment to be effective depends on Rosa's own judgment of Clara's interests.

But Clara's judgment that she needs Rosa's help rehearsing her lines concerned just those other interests and their comparative weights in the situation. Rosa's deliberations, insofar as they use Rosa's judgment of those interests, do not take Clara's judgment seriously as a judgment, as a prospective exercise of her agency in the pursuit of her end. Even though the end at issue is Clara's audition, Rosa's deliberations presume that when it comes to deciding what she (Rosa) is to do, the relevant judgment is not Clara's (reasonable) judgment that she needs Rosa's help; rather, it is Rosa's judgment that she does not combined with her judgment that, even so, Clara's interest in exercising choice outweighs those interests promoted by a successful audition. And so, even were Rosa to decide to help Clara rehearse her lines, she would not be acting on Clara's claim that she needs her help as Clara's judgment of her own interests but rather acting on it merely as a need Clara has to feel in control of the situation that, on Rosa's judgment, happens to outweigh those interests. Because it fails to take seriously Clara's judgment as a judgment, Rosa's deliberations fail to take Clara seriously here as a responsible agent pursuing her own ends and, in 
that way, they betray an attitude of condescension incompatible with proper respect for Clara and her capacity for responsible agency. Thus, this second proposal also fails to explain why Rosa ought to help Clara.

\subsection{Deference as a Duty of Friendship: Two Objections}

The result thus far is that, at least when it comes to certain disagreements about what to do that are confined to a friendship, friendship gives rise to a duty to defer. Before moving on to consider cases of moral disagreements that are not wholly confined to the friendship (for example, disagreements about whether to move a body), we need to consider two objections to this preliminary result.

The first objection is that a duty of friendship to defer to another, unlike a duty to defer generated by a promise, is incompatible with the duty-bearer's status as a responsible agent with her own valuable ends; and, since a person cannot be required to relinquish this status, friendship cannot include a duty to defer. On the account I've offered here, Subrena, in Promised Help, and Rosa, in Friend's Audition, each lack the full prerogative to deliberate and decide for themselves how they are to act. However, as this objection notes, Subrena lacks that prerogative because she has freely surrendered it; and, because it was up to her to surrender it (or not), she could still take her own ends seriously, making the promise only if she thought doing so were compatible with pursuing those ends. But, if Rosa has a duty to defer, it is one that she simply finds herself with, and so she simply finds herself deprived of that prerogative in favor of her friend and her friend's ends; this is objectionable from the perspective of Rosa's own status as a responsible agent, as she is unable, in her own deliberations, to take the pursuit of her own ends seriously. ${ }^{19}$

It is true, of course, that finding yourself without the full prerogative to deliberate for yourself is often a significant loss of control, as you are unable to tailor your actions to suit your ends; possessing this prerogative thus has instrumental value. It will often also have representative value for you: exercising this sort of control allows you to affirm your status as a responsible agent. ${ }^{20}$ But whether such control is valuable in these ways depends on the circumstances, and, in Friend's Audition, it is not. Persons can be friends with others - and so possess a duty in certain situations to defer to them - without the possession of that duty impairing their ability as responsible agents to take their own ends seriously.

Consider the context. Rosa cares deeply for Clara as an agent: she is

\footnotetext{
${ }^{19}$ This objection is a version, applied to this argument about deference in friendship, of a longstanding objection to proposed nonvoluntarist accounts of political authority and obligation. For one recent and sophisticated marshaling of this "voluntarist" objection, see A. John Simmons's work, particularly Simmons 1979 and 2001. I thank Jyl Gentzler for discussion of this objection. ${ }^{20}$ As T. M. Scanlon explains, the exercise of choice (or, as I put it here, the prerogative to deliberate and decide for oneself) has representative value when we have "reasons... for wanting to see features of ourselves manifested in actions" (Scanlon 1998, 252). For related discussion, see Elizabeth Anderson's discussion of gift exchange in Anderson 1993, 151-52.
} 
intimately aware of, sensitive to, and regularly moved to promote Clara's interests, including her interest in exercising her agency in the pursuit of her own ends. And, importantly, Clara reciprocates this care. Furthermore, Rosa trusts in Clara's care for her as an agent. As Karen Jones's account of trust has it, Rosa possesses "an attitude of optimism" about Clara's care for her as well as "the confident expectation" that, in the appropriate circumstances, Clara will be moved by this care (Jones 1996, 5-6). ${ }^{21}$ And, importantly, Clara reciprocates that trust. As a result, Rosa's deference has particular significance as expressing both her trust in and care for Clara. It expresses Rosa's trust in Clara in that, by deferring to Clara's judgment, Rosa hands her agency over to Clara (in a limited way) for her to do with what she thinks best; and Rosa's willingness to do so shows Clara that she trusts that Clara made this judgment thinking, not only of herself, but also of Rosa. ${ }^{22}$ It also expresses Rosa's care for Clara by satisfying an important interest Clara has as an agent-here, to have how she prepares for her audition depend on her own judgments - an interest to which Rosa ought to be specially responsive simply because it is Clara's. ${ }^{23}$

Rosa's care for, and trust in, Clara - and so Rosa's willingness to defer to Clara-are justified, in part, because Clara is willing to defer in similar situations to Rosa, and such willingness expresses Clara's care for, and trust in, Rosa. Were Clara unwilling to reciprocate this deference in those situations, Rosa would have reason to doubt both that Clara trusts her and that Clara cares for her in the right way, as an agent with her own valuable ends. ${ }^{24}$ And these doubts would rightly call into question the appropriateness of her deferring to Clara. Thus, Rosa must give Clara's interest in exercising agency in the pursuit of her ends this special importance in her deliberations - she must share Clara's ends in this way - only because Clara gives Rosa's interests, including her interest in exercising agency, a similar importance in her own deliberations. ${ }^{25}$

Deferring to Clara, then, is compatible with Rosa's status as a responsible agent because Rosa's deference is to someone who cares about her as an agent with her own valuable ends: the instrumental value that Rosa's deliberative prerogative has in protecting and promoting her interests is provided here by the character of their relationship. And so, were Rosa to refuse to defer to Clara, she would be holding herself back from Clara as a way to guard her ability to take

\footnotetext{
${ }^{21}$ As Jones $(1996,7)$ says, "When we trust a friend, the competence we expect them to display is a kind of moral competence. We expect a friend to understand loyalty, kindness, and generosity, and what they call for in various situations."

${ }^{22}$ Of course, Rosa may not be aware either that, by deferring to Clara, she is expressing her trust in Clara or that she is willing to defer to her, in part, because she trusts Clara and Clara's good will. Annette Baier notes that this sort of trust is normally unself-conscious. As she says, "The ultimate point of what we are doing when we trust may be the last thing we come to realize" (Baier 1986, 236).

${ }^{23}$ In this case, it is not only important that Clara be helped in this way but also that Rosa be the one to help her. For discussion of this feature of care for another, see Blustein 1991, 146, 150.

${ }^{24}$ Laurence Thomas $(1987,225)$ notes that a failure of friends to reciprocate indicates a lack of trust between them.

${ }^{25}$ To be clear, the argument here is about what justifies Rosa's willingness to defer to Clara when circumstances warrant it and not about what properly motivates Rosa, as Clara's friend, to defer to Clara in those circumstances.
} 
her own ends seriously; but, because doing so is unnecessary in the context of the mutual care and trust between them, it is incompatible with proper care for Clara as an agent. ${ }^{26}$ Their relationship thus makes it possible for Rosa and Clara to care for one another as responsible agents worthy of determining the course of their own lives - they can share the other's ends still very much as the other's - without thereby endangering their ability, as responsible agents, to take their own ends seriously. ${ }^{27}$ And, partly because of this, their friendship itself counts as an ongoing joint achievement that they each have reason to value. But to value it properly just is to possess the commitment to doing what the friendship requires; and so, when Rosa defers to Clara, she expresses a commitment to the friendship that is genuinely her own: it is one of her valuable ends. In this way, Rosa's deference in Friend's Audition properly counts not as a betrayal of her status as a responsible agent but rather as an expression of it.

The second objection targets the claim that Rosa's duty to defer, like Subrena's, is a moral duty. According to this objection, what's been argued for thus far - that Rosa, if she is to care for Clara as a friend, ought to defer to herdoesn't yet show that the 'ought' here is a moral one, since Rosa isn't morally required to care for Clara as a friend. (Friendships are morally optional relationships.) Thus, the most the argument shows, according to this objection, is that Rosa has merely a duty of friendship to defer to Clara, not that Rosa's duty, like Subrena's, is also a moral duty. ${ }^{28}$

Friendships are, as the objection notes, morally optional relationships: persons are free both to form (or, more commonly, to decline to form) friendships with others and to dissolve those friendships they're currently in. ${ }^{29}$ The objector takes this admission to be crucial for understanding the status of the duties generated by a friendship: "Aren't my duties," she wonders, "then

\footnotetext{
${ }^{26}$ Jeffrey Blustein $(1991,57)$ makes the related point that "[l]etting go of attempts to control partly characterizes the relationship of friends." In this way, my argument represents, to some extent, an addition to David Velleman's (1999) account of love. Velleman argues that love is "an arresting awareness" of the beloved's value, specifically an awareness that arrests "our tendencies toward emotional self-protection from another person, tendencies to draw ourselves in and close ourselves off from being affected by him" (Velleman 1999, 360-61). If my argument here is correct, love for a close friend arrests not only our tendencies to emotional self-protection but-insofar as it is love for the friend as an agent-also our tendencies toward what might be called practical or deliberative self-protection.

${ }^{27}$ This is not entirely true, for, even if your friend is motivated by the right reasons, her judgment may still be mistaken. (Friend's Audition is an example.) This risk of mistakes, however, simply comes along with friendship (or any such relationship) if it is to be a relationship in which each friend's interest in exercising agency is respected. And this sort of risk is the same as the risk a person assumes when they insist that their own interest in exercising agency be respected, for they may make mistakes that, had another chosen for them, could have been avoided.

${ }^{28}$ I thank Bennett Helm and Lee Franklin for discussion of this objection.

29 Though friendships can be entered into by (a more or less explicit) agreement - and so friendships can be based on consent-I think it more common for a person, after a period of doing friend-type things with another, to discover that they have become friends with that other, say, by finding themselves in a situation in which they need this other or vice versa. In these cases, although the friendship is not based on consent (or even entered into intentionally), it is a voluntary relationship, for they were free to refrain from doing with this other those friend-type things that standardly lead to friendship.
} 
contingent on my caring for my friend, thus making them hypothetical imperatives - 'If I care for him as a friend, I ought to do $x^{\prime}$-and so not yet moral duties?" The objector's mistake here, however, lies in confusing the claim that her duties are contingent on the friendship with the claim that they are contingent on her caring for him as a friend. Notice that the care at issue here is attitudinal care-the feelings of care for the other-and the objector is right to take this sort of care to be partly constitutive of friendship. ${ }^{30}$ Indeed, in a properly functioning friendship, these feelings of care are what motivate the actions of care: I act out of care for my friend, willingly (and even enthusiastically) fulfilling my duties of friendship toward him. However, I recognize at the same time that the force of my duties doesn't depend on whether, when they lay claim to my actions, I actually have those feelings of care or, if I fail to have them, on whether I am confident that this failure is only a temporary aberration; instead, it is the fact of our relationship-and, in particular, of our mutual commitments to care for one another as friends - that both grounds my duties of care for him and justifies my feelings of care for him. ${ }^{31}$ If I'm having a bad day, or if I'm rather grumpy, or if I'm just feeling a powerful sense of alienation from him - he strikes me at that moment as very much a stranger - and thus I fail to have the appropriate feelings of care, my duties of friendship nevertheless remain in force. And, if this failure to have these feelings proves persistent and stable such that I no longer count as caring for him as a friend, my duties of friendship remain in force until I make this failure public within our friendship, for it is only then that our relationship-and, in particular, the practical commitments to one another partly constitutive of it-is open to revision or even dissolution. ${ }^{32}$ Indeed, it would be difficult to explain the ways in which friends are able to rely on one another in the pursuit of shared ends were we to take these duties to be contingent in the way that the objection requires.

If it is the case that the force of my duties of friendship doesn't depend on whether, when they purport to lay claim to my actions, I actually do count as caring for my friend, then these duties seem quite plausibly understood as providing me with categorical reasons for action and thus as being moral duties, at least on standard conceptions of morality according to which, as $\operatorname{Raz}(1989,17)$

\footnotetext{
${ }^{30}$ This notion of attitudinal care is admittedly a bit rough. But I don't think that this is a problem here, for all that's needed is the claim that caring for (or loving) another requires, at least in part, that one have the appropriate feelings for that other and emotional responses to whether things go well or badly for them. Of course, fleshing this out is a complicated task. Bennett Helm does just that in Helm 2010, particularly chapters 2, 3 and 5.

${ }^{31}$ In other words, our friendship makes appropriate my having certain feelings of care toward you and even commits me to having those feelings; absent some special justification, my failure to have those feelings is, to a certain extent, criticizable: I'm being a bad friend. For related discussion, see Ebels-Duggan 2008, 143 n4.

${ }^{32}$ Making such a failure public in a friendship needn't require direct conversation but can instead be done by gradually drawing oneself away from the other - you two "drift apart" - in ways that aren't failures to fulfill your commitments but still signal to the other the weakening or dissolution of the friendship. He may find, for instance, that you don't spend as much time with him as you used to or that you are less interested in doing the things he enjoys, and he may rightly conclude that your relationship has changed or ended, even if you two never directly talk about it. What's important here is that the fact that you no longer care for him as a friend cannot, by itself, dissolve your friendship; rather, dissolution requires that you communicate that fact to him.
} 
puts it, "morality encompasses all categorical reasons" or, if not all, at least those categorical reasons governing one's interactions with others.

\section{FRIENDSHIP AND MORAL DISAGREEMENT}

The disagreement Clara and Rosa face in Friend's Audition is a disagreement confined to their friendship about whether Clara needs Rosa's help rehearsing her lines. My claim has been that Rosa, if she is to care for Clara as an agent, must defer to her judgment about whether to help her. And, again, this duty to defer - as well as the larger requirement to care for the other as an agent, of which this duty is a part - is not just a requirement of friendship but also a moral requirement, one that internally structures friendship. And so, were Rosa to refuse to defer to Clara, her refusal wouldn't be only a failure of friendship but also a moral failure.

What, then, about a situation of moral disagreement between friends, one that is not confined to the friendship? Could a friend have a duty to defer to the other's moral judgment? Consider the following situation, very loosely adapted from one in the film Death in Brunswick (Ruane 1990), ${ }^{33}$ involving two close friends, Carl and Dave, who must decide whether to hide a body:

The Circumstances of Brunswick: Carl works as a cook at a small-town nightclub. One evening his kitchen helper Mustapha is severely beaten in the alley by some local toughs, and Mustapha is told that Carl was responsible for it (he wasn't). Later that night, after closing, Mustapha goes after Carl in anger but, in doing so, impales himself on the large fork Carl is holding and dies. Soon after, Carl's close friend Dave arrives to pick him up from work. They now face an urgent decision: "What are we to do?"

There are two options: (a) call the police and wait for them to arrive so that Carl may give them his account of what happened, or (b) hide Mustapha's body that night in a grave at the isolated cemetery where Dave works, ensuring that Mustapha's death won't be discovered. ${ }^{34}$ What counts in favor of (a) and against (b)?

As they both know, Mustapha was a devoted husband and father. His wife and son deserve to know what happened to him. Were they to hide Mustapha's body, his wife and son will likely suffer substantial harms: the distress of not knowing where Mustapha is or even if he is alive; the worry that perhaps he abandoned them and, if so, that he really didn't love them the way they'd thought; the inability to mourn Mustapha and carry out proper burial rituals; and the inability of

\footnotetext{
${ }^{33}$ Cited in Cocking and Kennett 2000, 279. I have borrowed certain of the descriptions of the case from Cocking and Kennett, though, to be fair, my version of the case departs radically from theirs (and so also from the situation presented in the film).

${ }^{34}$ They cannot simply flee the nightclub, leaving Mustapha's body to be found the next morning, for doing so will not only ensure that Carl will be convicted of murder when he is eventually arrested and tried but will also likely put Dave in legal jeopardy as an accomplice.
} 
Mustapha's wife to begin in earnest building a life without him for herself and her son.

What counts in favor of (b) and against (a)?

As they both know, the local police are quite corrupt, often working with the drug gang that employs the toughs who beat up Mustapha. They are certain to ignore Carl's account in order to close the case without implicating the toughs (and so the gang). Thus, Carl is quite likely to be convicted of a crime he did not commit. Furthermore, as they both know, the prison system is severely underfunded and rife with violence. Carl is slightly built, and he suffers from chronic diabetes and a heart condition. Were they to call the police, Carl will likely suffer substantial harms in prison: the routinized arbitrary violence meted out by guards; rape and other forms of sexual violence at the hands of other inmates; and deteriorating health and even early death because of a lack of proper treatment from the prison's woefully inadequate medical facilities.

Whichever option they choose, Dave's help is required. For option (a), Dave must give Carl his cell phone if Carl is to call the police, as Carl doesn't have one - he cannot afford one- and the nightclub's phone is out of order. For option (b), Dave must not only help Carl move the body, but he also must unlock the cemetery and locate the grave that is to be filled in the next morning. ${ }^{35}$

The end at stake, which Dave shares with Carl, is to keep Carl from going to jail for a crime he didn't commit. Let us suppose that, after deliberating together, Carl and Dave disagree about how to pursue that end. Of course, there are several ways they could disagree, but I wish to focus on two:

Brunswick 1: Carl thinks that hiding Mustapha's body is morally permissible and so he judges that (b), hiding the body, is the right decision, while Dave thinks that doing so forbidden and so he judges (a), calling the police, to be the right decision.

Brunswick 2: Carl thinks that hiding Mustapha's body is morally forbidden and so he judges that (a), calling the police, is the right decision, while Dave thinks that doing so permissible and so he judges (b), hiding the body, to be the right decision.

In each case of disagreement, one friend thinks it is impermissible to pursue their shared end of keeping Carl out of prison in the way that the other proposes. ${ }^{36}$

\footnotetext{
${ }^{35}$ For another case of hiding a body in a cemetery, one that proves quite successful until one of the persons involved confesses to the police, see series 2 of Broadchurch (Chibnall 2015). For a case of hiding a body, one in which hiding the body seems quite clearly morally permissible (and perhaps even morally required), see series 2 of Luther (Cross 2011). For a more morally ambiguous case of hiding a body - the killing is arguably justified, but the friends' fear of wrongful imprisonment may not be a reasonable fear-see season 2 of Friday Night Lights (Berg 2007).

${ }^{36}$ The judgment that hiding Mustapha's body is impermissible does not amount to abandoning the end of keeping Carl out of prison, as the path from the nightclub to prison will be a winding one, and, even if they notify the police and Carl is arrested, there will likely be other, admittedly much
} 
And, in each, Dave, as Carl's friend, confronts the following: "What am I to do here? Should I help Carl act on his judgment? Or should I try to act on mine?"

The aim of this essay is to show that a good friend sometimes has a moral duty to defer to his friend's (mistaken) moral judgment, even when doing so requires helping him hide a body. And so, Brunswick 1 might seem the case on which to focus. However, the claim about Brunswick 1 that Dave, despite his moral worries, should help Carl hide the body is open to another, competing explanation, one provided by the "moral danger" account: acting properly as a friend, that is, acting out of a concern for your friend's good for your friend's sake, can sometimes require acting against morality; and Brunswick 1 is one such case, as Dave does the appropriate thing by acting as his friendship with Carl calls for, and thus hiding the body, rather than acting as morality requires, and thus calling the police. ${ }^{37}$

Fortunately, the claim, about Brunswick 2, that Dave ought to help Carl call the police also requires explanation, since offering such help seems precisely not to be acting out of a concern for Carl's good. We must explain why it is that proper care for a friend sometimes requires, as it does here in Brunswick 2, helping him act against his own good, even when one reasonably judges that such action is not morally required. As I argue, the correct explanation is that Dave has a duty to defer to Carl in Brunswick 2, since doing so is the way for Dave, as his friend, to care for him as a responsible moral agent. And, once we have that explanation available for Brunswick 2, it also becomes available for Brunswick 1, thus giving us a way to claim that Dave rightly helps Carl hide Mustapha's body without that claim requiring us to admit that, in Brunswick 1, the demands of friendship override the demands of morality; and this will be so even on the assumption that Carl's judgment-hiding Mustapha's body is permissible - is, in fact, mistaken. Thus, the argument begins with Brunswick 2.

\subsection{Why Must a Good Friend Help You Call the Police?}

Because of the circumstances of Brunswick, Carl and Dave face a hard moral decision: there are genuinely weighty moral considerations on both sidesconsiderations for and against either option - and it is, I think, quite difficult to determine what morality says about the case. Mustapha's wife and son are innocents, but so is Carl. The harms Carl will likely suffer by going to prison for a crime he didn't commit are arguably more severe than those Mustapha's wife and son will likely suffer were Carl and Dave to hide Mustapha's body; but, then again, the course of the police investigation and trial may provide other opportunities for Carl to avoid prison, and, even if the chances are slight, that there may be such opportunities is morally relevant. Thus, it is not only a question of comparing possible harms (and the number of sufferers) but also a

less promising, opportunities to pursue this end. The judgment is rather that even though the end is certainly a permissible one, it is impermissible to pursue it by hiding Mustapha's body. ${ }^{37}$ Dean Cocking and Jeanette Kennett (2000) offer a sustained defense of this "moral danger" explanation. 
question of weighing the odds of those harms; and the result seems to be a genuinely hard moral case. (And I say this as someone sympathetic to the thought that the prohibition against hiding a body has the status of a side constraint, because even side constraints give way at times.) Granted, not every reader will agree that this is a hard moral case. But, for those readers, I expect that there will be some realistic detail(s) that, when added to the circumstances of Brunswick, will transform it into such a case; if you are such a reader, I ask that you add those details.

Why does it matter that Brunswick is a hard moral case? By admitting that it is such a case, we must also admit that Dave and Carl may each deliberate responsibly about what to do, making no deliberative mistakes, and yet arrive at conflicting moral judgments. Put as a slogan, hard moral cases give rise to reasonable moral disagreement. Now, this claim is not a terribly controversial one, since it is widely accepted that any conception of moral deliberation that guarantees correctness of judgment will be fit only for an idealized moral agent who, because they lack the limitations that humans inevitably face, is not a human agent. ${ }^{38}$ Any plausible conception of moral deliberation for human agents must admit the real possibility of moral disagreements that cannot be explained by pointing to deliberative mistakes on either side. ${ }^{39}$

When it comes to understanding what goes into caring for a friend as a responsible agent, however, the full significance of this claim - that hard cases give rise to reasonable disagreement - has gone unappreciated. As I noted earlier, a friend shares the other's ends, and this sharing involves, at times, acting with them in pursuit of those ends. But now, with this claim about reasonable disagreement, acting with them in a way compatible with caring for them as an agent (including as a moral agent) becomes a more complicated question, since the following sort of situation is possible:

Though the friend disagrees with the other's judgment about what to do-he thinks it's morally mistaken - he recognizes that her judgment was the result of responsible deliberation: her deliberations properly appreciated the moral features of the situation, of what made the case a hard one, and that her deliberations do this is all that he (or anyone else) may legitimately expect of her as a human agent taking proper responsibility for her actions. Despite their disagreement, he recognizes that her deliberations have passed the test of responsible moral agency in a situation that has particular significance for one of her valuable ends.

\footnotetext{
${ }^{38}$ John Rawls $(2001,35-37)$, in a different context, calls these inevitable limitations "the burdens of judgment," which are "the many obstacles to the correct (and conscientious) exercise of our powers of reason and judgment in the ordinary course of political life." Rawls's emphasis is often on the consequences of these burdens for our judgments of the good; but, as Jeremy Waldron $(1999,153)$ argues, there seems no reason not to take these burdens to have similar consequences for our judgments about justice and morality. For related discussion, see Charles Larmore's (1996, 152-74) treatment of reasonable disagreement and pluralism.

${ }^{39}$ And so, we are concerned here not with, for instance, R. M. Hare's "archangel" but rather with what Barbara Herman calls "a morally literate agent." See Hare 1981, 44-64 and Herman 2000, 3133.
} 
Let's assume that Dave faces just this situation in Brunswick 2: Carl's judgment that they must call the police passes the test of responsible moral agency, but Dave reasonably disagrees with it. ${ }^{40}$ Why ought Dave help Carl call the police? The first thing to note is that, because they reasonably disagree about this hard case, there is nothing more they can do as human deliberators to get closer to the answer about what morality demands. ${ }^{41}$ As a result, they now face a new deliberative situation, one of reasonable disagreement about what judgment to make in the former situation, and so a new question about what to do. And this new question is itself a moral question that cannot be answered simply by saying that they should do whatever morality demands in the former situation. Both Carl's and Dave's judgments about the former situation are reasonable, and so, even though they conflict-and would have importantly different consequences both for Carl and for Mustapha's wife and son-each still counts as motivated by proper moral concern both for Mustapha's wife and son and for Carl.

In Brunswick 2, then, the problem concerns what Carl and Dave should do in this new situation of reasonable disagreement, and the answer depends on the nature of their relationship. Were they strangers, all that each would need to do is acknowledge the other's reasonable view, and acknowledge it as reasonable, before acting on their own (reasonable) judgments. ${ }^{42}$ But, since Carl and Dave are close friends, Dave must care for Carl as an agent. Given that this situation has particular significance for Carl, it would be seriously disrespectful for Dave to insist on making the decision in Brunswick 2-and so for him to insist that they hide Mustapha's body-because were he to do so, he would be taking responsibility for the decision away from Carl even though Carl's judgment passes the test of responsible moral agency. Were he to do it out of concern for Carl, he would be acting paternalistically - "It's better for you if $I$ decide what we $\mathrm{do}^{\prime \prime}$ - and so in a way incompatible with friendship as a relationship of equals. Were he to do it out of a concern for himself and his own integrity - "I must do what $I$ think is right here" - he would be holding himself separate from Carl in a way incompatible with friendship. And this is true even though he'd be seeing to it that Carl doesn't go to prison, for what Dave would be revealing is that he is unable to share Carl's end in a way that still allows it to be Carl's; he can only

\footnotetext{
${ }^{40}$ Why think that either judgment can be reasonable? That Carl's judgment can be seems easy to establish, for we'd just need to make sure his judgment is not driven by a lack of self-respect that leads him not to count his own life and interests as morally on a par with others'. That Dave's judgment can be reasonable seems harder to establish, since one might think that, as Carl's friend, Dave is bound to be overly partial, wrongly minimizing the harms to Mustapha's wife and son. But suppose that Dave, like many, has a tendency toward rule-fetishism. In that case, were Carl not his friend, his commitment to the rule that hiding a body is forbidden would cause him to wrongly minimize the harms to Carl of calling the police. This tendency would thus lead him to fail to see that this is a hard case. But, since they are friends, these harms to Carl will be salient to him: he will perceive them as important moral features of the situation. In this sort of case, then, Carl's status as his friend will be what rescues his deliberations from a common kind of moral blindness.

${ }^{41}$ This is partly because, in the circumstances of Brunswick, matters are rather urgent and so they cannot delay a decision in the hope that new evidence will emerge to tip the scales decisively in one direction or the other. I thank an anonymous reviewer for prompting me to make this explicit. ${ }^{42}$ Acknowledging that the other person's view is reasonable-admitting that you see how the other could responsibly disagree-is an important sign of respect for the other's judgment, particularly in the case of disagreement between strangers.
} 
share it in a way that appropriates it as his own. Either way, denying Carl the chance here to take responsibility for the situation by responsibly exercising his moral agency is incompatible with caring for Carl as an agent.

Thus, the fact that Dave and Carl are good friends in Brunswick 2 is morally salient. But, again, we must be clear about its precise relevance. It should not enter their deliberations about the morality of moving Mustapha's body or calling the police. Rather, it is a salient feature of the later deliberative situation that Dave faces, the situation of reasonable disagreement between him and Carl about whether or not to hide Mustapha's body, and it is so because of Dave's duty of care toward Carl. As Carl's friend, Dave must show proper care for Carl by giving his needs and interests special importance in his deliberations, including Carl's interest in responsibly exercising his moral agency. And this interest is especially important here: the initial situation (and the moral problem it poses) is especially significant for Carl's end of avoiding life imprisonment for a crime he did not commit. Because this initial situation is not particularly significant for Dave and his ends (except, of course, for his end of being a good friend to Carl), Dave's interest in doing what he reasonably thinks right does not compete with Carl's. Thus, both PAI and RJ are satisfied here and in Carl's favor. Dave must defer to Carl here because doing so expresses not only the depth of his care for Carl but also the character of that care, as care for Carl as a responsible agent with sovereignty over his own life.

If this account of Brunswick 2 is correct, one result is that a person's interest in exercising agency extends even to moral questions and, in particular, those moral questions that admit of reasonable disagreement. When a person acts on their own reasonable moral judgments in difficult situations whose resolution will significantly shape their life, what happens - both the actions and their consequences-expresses their own moral sensibility and so counts as part of the moral world that they have created; the person thus takes responsibility for and invites others to hold them responsible for what happens, thereby demanding recognition both as a moral agent and as a reasonable one. ${ }^{43}$ In this way, they have reason to value the responsible exercise of their moral agency, particularly in situations that are significant for them, and their friends have reason to accommodate and promote this exercise.

\subsection{When Does a Good Friend Help You Move a Body?}

Notice that, as PAI has it, whether Dave has a duty to defer to Carl in Brunswick 2 depends on the extent to which the situation they face is significant for Dave. If, for instance, Dave's presence were likely to cause the police to think him an accomplice to murder, Dave would not have a duty to defer to Carl's

\footnotetext{
${ }^{43}$ The claim here is similar to Raz's account of self-respect, in which he says, for instance, that "the self-respecting person holds that others should treat [her] as someone who is capable of rational responsible agency" (Raz 1989, 15).
} 
judgment that they should call the police. ${ }^{44}$ Because going to jail would significantly alter Dave's life, he and Carl would each have reason to insist on responsibly exercising their own moral agency in Brunswick 2; Dave, then, would be justified in acting on his own reasonable judgment that it is permissible to hide Mustapha's body. It would be appropriate for Carl to feel disappointed by Dave's decision, since he would be unable to rely on the friendship in the way that he thought appropriate, but not betrayed, since Dave's decision to act on his own judgment would not count as a failure to care properly for Carl.

On the account I've offered, so long as both conditions-PAI and RJ-are satisfied in Carl's favor, Dave has a duty to defer to Carl's judgment. Dave's duty, then, does not depend on Carl's making the particular reasonable judgment he does. And so, let us now consider Brunswick 1:

Brunswick 1: Carl thinks that hiding Mustapha's body is morally permissible and so he judges that (b), the hiding body, is the right decision, while Dave thinks that doing so is forbidden and so he judges (a), calling the police, to be the right decision.

Carl's and Dave's judgments are switched: Carl thinks that hiding Mustapha's body is permissible, while Dave thinks that doing so forbidden. Assuming that Carl's judgment here is reasonable, my account claims that Dave has a duty as Carl's friend to defer to him. ${ }^{45}$ Furthermore, it claims that, since deferring to Carl is required if Dave's care for Carl is to be care for him as an agent, Dave doesn't merely do what loyal friendship requires when he defers to Carl; he also does the morally justified thing, even if Carl's judgment about the permissibility of hiding Mustapha's body is, in fact, mistaken. Here, then, is the kind of situation where, despite his own moral worries, a good friend will (rightly) help you move a body.

Of course, this duty to defer to a friend's reasonable moral judgments-even about the permissibility of moving a body-obtains only when the relationship is already characterized by the appropriate relations of mutual care and mutual trust. Dave must give Carl's interest in exercising moral agency this special importance in his deliberations only because Carl regularly gives Dave's interest in exercising moral agency, along with his other interests, the same special importance. There is, however, an extra condition on the duty to defer when it concerns moral questions, and it is clearest when considering a case such as

${ }^{44}$ There is an added difficulty here, however: the more risk there is to Dave, the less Carl's view that they ought to call the police is reasonable, for Carl's deliberations must be informed by care for Dave.

${ }^{45}$ Why think that either judgment here can be reasonable? Consider Dave's judgment. Dave is in a very good position to appreciate the harms that Carl will suffer if they call the police, but that he nevertheless thinks that doing so is required suggests that he also appreciates the harms

Mustapha's wife and child will suffer if they hide the body. That Carl's judgment can be reasonable might seem harder to justify. But suppose that Carl, like many, has a tendency toward rulefetishism, one which would normally lead him wrongly to minimize the harms resulting from a decision to abide by the rule that hiding a body is forbidden; here, then, the fact that the harms will befall him is actually what makes them salient to him as important moral features of the situation and so leads him to see that this is in fact a hard case. 
Brunswick 1: Dave must be justified in trusting not only that Carl cares for himand so is motivated in his choices by this care-but also that Carl is committed to acting morally - and so is motivated in his choices by this commitment. Without this latter sort of justified trust, Dave lacks sufficient reason to think that, by deferring to Carl, he is actually respecting and promoting Carl's interest in responsibly exercising moral agency. And it is only if Dave is respecting and promoting this interest by deferring that his deference would be justifiable, say, to Mustapha's wife, because it is only then that his deference counts as the action of a good friend and responsible moral agent. ${ }^{46}$

If we assume, as seems plausible, that Carl's judgment about hiding Mustapha's body (though reasonable) is mistaken, it might seem that my claim here is that Dave is morally required to commit a grave moral wrong. But this way of putting it fails to distinguish between the two deliberative situations. In the circumstances of Brunswick, Dave, as Carl's close friend, must do what Carl reasonably thinks ought to be done. Dave does act on his own judgment when he helps Carl, but that judgment is the one he makes in the later situation created by their reasonable disagreement. And, if we suppose his judgment there is correct-Carl's judgment that they should hide the body is a reasonable oneDave does not commit a grave moral wrong in acting on it, even though his judgment is that he ought to defer to Carl's (mistaken) judgment about the initial situation. ${ }^{47}$ Granted, the account does let Dave off the moral hook, so to speak. ${ }^{48}$ But what gets Dave off the hook - he is Carl's close friend-also puts Carl doubly on the moral hook: he is responsible not only for the decision to hide Mustapha's body but also for making use of Dave's friendship in the way he does.

\subsection{A Good Friend Will Help You Move a Body: Two Objections}

Before concluding the argument, we need to consider two objections. Both challenge the claim that, because Dave's duty to defer doesn't depend on Carl making the particular reasonable judgment he does, Brunswick 1 and Brunswick 2 are thus symmetrical.

\footnotetext{
${ }^{46}$ Why should Mustapha's wife recognize that Dave had a duty to defer to Carl? She is someone who is engaged in relationships of love and so she sees herself as having special responsibilities toward those she loves. As Niko Kolodny $(2003,153)$ notes, to love someone is, in part, to recognize that anyone in the same sort of relationship will have the same special responsibilities toward their beloved as one has to one's own. And so, as someone who has (or once had or is capable of having) a close friend, Mustapha's wife must admit that all close friends, including Carl and Dave, have duties of friendship toward each other.

${ }^{47}$ I thank Nishi Shah for discussion on this point.

${ }^{48}$ Dave is off the hook here only because he makes the correct judgment about deferring to Carl. But this decision is itself a hard one, for it depends on judging whether Carl's judgment is reasonable. And so, Dave is still on the moral hook in an important way: his decision about whether he ought to defer to Carl or not is a significant moral decision for which he is responsible. And this is itself a morally risky decision to make, particularly if Sarah Stroud's $(2006,499)$ claim that "friendship involves not just affective or motivational partiality but epistemic partiality" is correct, for then Dave's friendship with Carl might make him prone to misjudging Carl's judgments as reasonable. For Stroud's defense of this claim, see Stroud 2006.
} 
The first objection is directed at the claim that, even if Carl's judgment in Brunswick 1 is mistaken, Dave does the morally justified thing by helping Carl. How can it be morally justified, one might wonder, for someone to help a friend hide a body when doing so may in fact be a serious moral wrong? If it cannot be, then perhaps Brunswick 1 is a limiting case for the duty to defer: while Dave may have a duty to defer to Carl's (reasonable) judgment in Brunswick 2, he does not in Brunswick 1 because of the greater moral risk Carl runs in Brunswick 1, if hiding the body is not in fact permissible, than he runs in Brunswick 2, if calling the police is not in fact required. The thought here is that, when faced with two reasonable but conflicting moral judgments, one should help a friend act on the judgment that, were it mistaken, it would be morally better for him to have acted upon than it would be for him to have acted on the other, were that one mistaken. And, in this case, it is morally worse to act on the mistaken judgment that one may permissibly choose that innocent others will suffer serious harms than it is to act on the mistaken judgment that one must suffer serious harms instead. ${ }^{49}$

The problem with this objection is that, even if it is correct about the differences in moral risks one runs in acting on either judgment, these considerations are ones that Carl and Dave are to include in their initial deliberations about what to do, since responsible moral deliberation requires seriously considering the possibility that one might be mistaken. In other words, if Carl's judgment that it is permissible to hide Mustapha's body is reasonable, then his deliberations will have already canvassed these considerations about moral risks, and so these considerations don't provide a way for Dave to resolve his question of what he is to do, given that he and Carl reasonably disagree about whether to call the police or hide Mustapha's body. ${ }^{50}$

The second objection concerns the fact that, in Brunswick 2, Carl's judgment is that he is the one to suffer harm, while, in Brunswick 1, his judgment is that Mustapha's wife and child are the ones to suffer harm. According to this objection, this difference between the cases matters for the question of deference that Dave faces because, while the former judgment is a morally admirable one for Carl to make - he is, in a way, martyring himself for the sake of innocent others - the latter is not-he is acting in a morally cowardly way, shifting the harm from himself onto innocent others - and Dave, as Carl's friend, should only help him carry out the judgment that, even though he disagrees with it, is a morally admirable one for Carl to make. It is important to note, about this objection, that my account is vulnerable to it only if it admits that Carl's judgment in Brunswick 1-hiding Mustapha's body is permissible-can be (and, for the sake of argument, is) a reasonable one, since otherwise my account is not committed to the conclusion, which the objection targets, that Dave ought to defer to Carl. The objection's claim, then, is that, even supposing that Carl's

\footnotetext{
49 The objection here is a two-person version of a view about what an individual should do in the face of moral (or normative) uncertainty that Andrew Sepielli has considered in his recent work. See, for instance, Sepielli 2009 and 2014. I thank an anonymous reviewer for bringing Sepielli's work to my attention.

${ }^{50}$ I thank Lee Franklin for discussion of this objection.
} 
judgment in Brunswick 1 is reasonable, what Carl does in making that judgment-he decides that they should hide Mustapha's body - shifts the harm at issue on to others in a morally cowardly way, and Dave, as Carl's friend, ought not help Carl act in such a way.

This objection does not succeed either. In Brunswick 1, Carl's judgment that it is permissible to hide Mustapha's body is reasonable (we are supposing), and that it is shows that he is committed, as a responsible moral agent must be, to pursuing his ends in only morally permissible ways. Now, as this objection notes, what is permissible may still not be morally admirable but rather morally cowardly; here, even if it is permissible to hide Mustapha's body, it would nevertheless be morally better (because morally admirable) for Carl to call the police. The problem with the objection, however, is that, unlike the commitment to pursuing his ends in only morally permissible ways, the commitment to acting in morally admirable ways (and not in morally cowardly ways) will be only one among several of Carl's valuable ends. Part of what a responsible agent with sovereignty over their own life does is manage the often competing claims of their various ends on their choices and actions: they must decide which ends to pursue, which to postpone, which to forsake; they must decide how important some end(s) is (are) relative to some other competing one(s); they must decide what they are willing to do (and unwilling to do) in the pursuit of some end(s). In Brunswick 1, Carl has decided that he is not willing to spend his life in prison for a crime that he did not commit - thereby forsaking all of his ends that require freedom and participation in society - so that he might do the morally admirable thing. If Dave is to care for Carl as a responsible agent, he must recognize that this is Carl's decision to make, since it is not just a decision to be a moral coward but also a decision to pursue whatever valuable ends-going to college, pursuing a career, starting a family, traveling the world - he has judged worth the cost of that cowardice.

\section{CONCLUSION}

This account of the duty to defer provides a way of affirming, for certain situations, the insight about close friendship contained in the joke, "A friend will help you move house, but a good friend will help you move a body," without thereby being forced into the view that friendship has an inherent tendency to lead one into moral danger. In situations like Brunswick, there is often an important conflict-between realizing the duties of loyal friendship and doing what one otherwise takes to be morally correct - but this sort of conflict might nevertheless be internal to morality. My aim has been to develop an account of how this conflict might indeed be internal to morality: because morality requires that one's care for a friend be care for them as an agent, one will sometimes have a duty to defer to them, even about moral questions.

And so, one difficulty with close friendship is that, by becoming friends with another, a person assumes some risk that their friend will call on them for help and, in doing so, place them in a situation in which they face a distinctive kind of hard moral decision - “Do I defer to my friend's moral judgment, one I think 
mistaken? Or do I act on my own?" - one for which they are responsible. However, if we are to hold that, because of the great good that this kind of friendship realizes for persons, it is permissible for persons to form such friendships, we are committed to holding that this is a morally permissible risk for them to take.

\section{REFERENCES}

Anderson, Elizabeth. 1993. Value in Ethics and Economics. Cambridge, MA: Harvard University Press.

Baier, Annette. 1986. “Trust and Antitrust." Ethics 96: 231-260.

Berg, Peter. 2007. Friday Night Lights, Season Two. New York: NBC Universal Television.

Blustein, Jeffrey. 1991. Care and Commitment: Taking the Personal Point of View. New York: Oxford University Press.

Chibnall, Chris. 2015. Broadchurch, Series Two. London: Kudos Film and Television, for ITV.

Christensen, David. 2007. “Epistemology of Disagreement: The Good News.” Philosophical Review 116: 187-217.

Cocking, Dean and Jeanette Kennett. 1998. "Friendship and the Self." Ethics 108: 502-527.

----. 2000. “Friendship and Moral Danger." Journal of Philosophy 97: 278-96.

Cross, Neil. 2011. Luther, Series 2. London: BBC.

Ebels-Duggan, Kyla. 2008. “Against Beneficence: A Normative Account of Love." Ethics 119: 142-70.

Elga, Adam. 2007. "Reflection and Disagreement." Noûs 41: 478-502.

Frankfurt, Harry. 1999. Necessity, Volition and Love. New York: Cambridge University Press.

Fried, Charles. 1981. Contract as Promise: A Theory of Contractual Obligation. Cambridge, MA: Harvard University Press.

Friedman, Marilyn. 1993. What Are Friends For? Ithaca, NY: Cornell University Press.

Hare, R. M. 1981. Moral Thinking: Its Levels, Methods and Point. New York: Oxford University Press.

Helm, Bennett. 2010. Love, Friendship, and the Self. New York: Oxford University Press.

Herman, Barbara. 2000. "Morality and Everyday Life." Proceedings of the American Philosophical Association 74: 29-45.

---- 2008. "Morality Unbounded." Philosophy and Public Affairs 36: 323-358.

Hill, Thomas. 1991. "Servility and Self-Respect." In Autonomy and Self-Respect, 4-18. New York: Cambridge University Press.

Jones, Karen. 1996. “Trust as an Affective Attitude." Ethics 107: 4-25. 
Kelly, Thomas. 2005. "The Epistemic Significance of Disagreement." In Oxford Studies in Epistemology, Vol. 1, ed. John Hawthorne and Tamar Gendler, 167-96. New York: Oxford University Press.

Kolodny, Niko. 2003. “Love as Valuing a Relationship." Philosophical Review 112: 135-89.

Korsgaard, Christine. 1992. "Creating the Kingdom of Ends: Reciprocity and Responsibility in Personal Relations." Philosophical Perspectives 6: 305-32.

Larmore, Charles. 1996. The Morals of Modernity. New York: Cambridge University Press.

Montaigne, Michel de. 2005 [1580]. On Friendship. trans. M. A. Screech. New York: Penguin Books.

Rawls, John. 2001. Justice as Fairness: A Restatement. Cambridge, MA: Belknap Press. Raz, Joseph. 1986. The Morality of Freedom. New York: Oxford University Press.

----. 1989. "Liberating Duties." Law and Philosophy 8: 3-21.

Roth, Abraham Sesshu. 2004. "Shared Agency and Contralateral Commitments." Philosophical Review 113: 359-410.

----. 2013. "Prediction, Authority, and Entitlement in Shared Agency." Nô̂s 48: 626-652.

Ruane, John, dir. 1990. Death in Brunswick. 109 min. Sydney: Roadshow Entertainment.

Scanlon, T. M. 1998. What We Owe to Each Other. Cambridge, MA: Belknap Press.

Scheffler, Samuel. 2001. "Relationships and Responsibilities." In Boundaries and Allegiances, 97-110. New York: Oxford University Press.

Sepielli, Andrew. 2009. "What to Do When You Don't Know What to Do." Oxford Studies in Metaethics, Vol. 4, ed. Russ Shafer-Landau, 5-28. New York: Oxford University Press.

----. 2014. “What to Do When You Don't Know What to Do When You Don't Know What to Do..." Noûs 48: 521-544.

Shapiro, Scott. 2002. "Authority." In The Oxford Handbook of Jurisprudence and Philosophy of Law, ed. Jules Coleman and Scott Shapiro, 382-439. New York: Oxford University Press.

Shiffrin, Seana. 2008. "Promising, Intimate Relationships, and Conventionalism." Philosophical Review 117: 481-524.

Simmons, A. John. 1979. Moral Principles and Political Obligation. Princeton: Princeton University Press.

----. 2001. Justification and Legitimacy: Essays on Rights and Obligations. New York: Cambridge University Press.

Soper, Philip. 2002. The Ethics of Deference. New York: Cambridge University Press. Stroud, Sarah. 2006. "Epistemic Partiality in Friendship." Ethics 116: 498-524.

Thomas, Laurence. 1987. "Friendship." Synthese 72: 217-236.

Velleman, David. 1999. “Love as a Moral Emotion.” Ethics 109: 338-74. 
Waldron, Jeremy. 1999. "Rawls' Political Liberalism." In Law and Disagreement, 149163. New York: Oxford University Press.

Westlund, Andrea. 2003. "Selflessness and Responsibility for Self: Is Deference Compatible with Autonomy?" Philosophical Review 112: 483-523.

----. 2009. "Deciding Together." Philosophers' Imprint 9: 1-17.

Wolf, Susan. 1982. "Moral Saints." Journal of Philosophy 79: 419-439. 